AKUNTANSI: Jurnal Akuntansi Integratif

Vol.6 No. 2 Tahun 2020

p-ISSN 2502-5376 e-ISSN 2715-0658

\title{
PENGARUH TRANSPARANSI, AKUNTABILITAS, DAN IGCG TERHADAP TINGKAT KEPERCAYAAN MUZAKKI DI LEMBAGA AMIL ZAKAT DOMPET AMANAH UMAT
}

\author{
Mochammad Ilyas Junjunan ${ }^{1}$ \\ M. Maulana Asegaf ${ }^{2}$ \\ Moh. Takwil ${ }^{3}$
}

\author{
Universitas Islam Negeri Sunan Ampel Surabaya ${ }^{1,2,3}$ \\ E-mail: $\underline{\text { mij@uinsby.ac.id }}^{1}, \underline{\text { m.maulana@uinsby.ac.id }}^{2}, \underline{\text { syabab261@gmail.com }}^{3}$
}

\begin{abstract}
ABSTRAK
Tujuan penelitian ini untuk mengetahui pengaruh transparansi, akuntabilitas dan Islamic good corporate governance terhadap tingkat kepercayaan muzakki di lembaga amil zakat dompet amanah umat Kabupaten Sidoarjo. Populasi penelitian ini adalah seluruh muzakki tetap yang ada di lembaga amil zakat DAU Kabupaten Sidoarjo dan 42 responden yang berpartisipasi dalam penelitian. Teknik analisis penelitian menggunakan regresi linear berganda dengan taraf signifikan 5\% dan menggunakan pengujian t-tabel. Hasil penelitian yang didapatkan menunjukkan bahwa transparansi dan penerapan Islamic good corporate governance mampu mempengaruhi secara signifikan dan positif tingkat kepercayaan muzakki. Sementara akuntabilitas dalam penelitian ini tidak mampu mempengaruhi tingkat kepercayaan muzakki pada lembaga amil zakat dompet amanah umat Kabupaten Sidoarjo.

Kata kunci: Transparansi, Akuntabilitas, Islamic Good Corporate Governance
\end{abstract}

\section{ABSTRACT}

The purpose of this study was to determine the effect of transparency, accountability and Islamic good corporate governance on the level of trustworthiness muzakki in dompet amanah umat amil zakat institution, Sidoarjo Regency. The population of this research is all permanent muzakki in the DAU amil zakat institute of Sidoarjo Regency and 42 respondents who participated in the study. The research analysis technique used multiple linear regression with a significant level of $5 \%$ and used t-table testing. The results obtained indicate that transparency and the application of Islamic good corporate governance are able to significantly and positively influence the trust level of muzakki. Meanwhile, the accountability in this study is not significantly able to influence the level of trust of muzakki in the dompet amanah umat amil zakat institution of Sidoarjo Regency.

Keywords: Transparency, Accountability, Islamic Good Corporate Governance

\section{Pendahuluan}

Zakat sebagai salah satu rukun di dalam agama Islam memiliki peranan yang penting dalam membangun ekonomi masyarakat. Sebagai salah satu asset pada lembaga ekonomi 
islam, zakat merupakan sumber dana potensial yang strategis bagi usaha dalam membangun kesejahteraan umat (Atabik, 2015). Dalam Q.S. At-Taubah ayat 103 yang berbunyi:

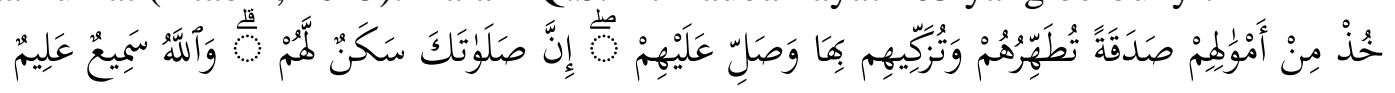

Dari kandungan ayat tersebut menunjukkan bahwa zakat merupakan kewajiban seorang muslim yang mampu untuk dikelola dan diberikan kepada mereka yang berhak menerimanya. Dalam konteks ekonomi, zakat bisa berperan dalam pencegahan terhadap penumpukan kekayaan pada segelintir orang dan mewajibkan orang kaya untuk mendistribusikan harta kekayaannnya kepada 8 kelompok yang berhak menerima zakat dalam Q.S at-Taubah ayat 60 yang berbunyi:

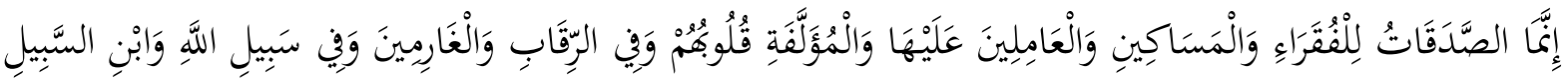

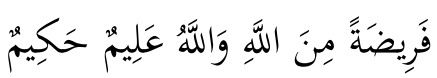

"Sesungguhnya zakat-zakat itu, hanyalah untuk orang-orang fakir, orang-orang miskin, pengurus-pengurus zakat, para mu'allaf yang dibujuk hatinya, untuk (memerdekakan) budak, orang-orang yang berhutang, untuk jalan Allah dan untuk mereka yuang sedang dalam perjalanan, sebagai suatu ketetapan yang diwajibkan Allah, dan Allah Maha Mengetahui lagi Maha Bijaksana”. Dengan demikian, zakat juga berperan sebagai sumber dana yang potensial untuk mengentaskan kemiskinan (Rozalinda, 2016).

Pengelolaan zakat bertujuan untuk meningkatkan pelayanan bagi masyarakat dalam menunaikan zakat sesuai dengan tuntunan agama, meningkatkan fungsi dan peranan pranata keagamaan dalam mewujudkan kesejahteraan masyarakat dan keadilan sosial, serta meningkatkan hasil guna dan daya guna zakat (Ghofur, 2010). Organisasi pengelola zakat di Indonesia terdiri atas Lembaga Amil Zakat dan Badan Amil Zakat. Badan Amil Zakat dibentuk oleh pemerintah dibawah naungan Kementerian Agama dan tersebar hampir di setiap kecamatan, kabupaten, hingga provinsi (Purbasari, 2015). Sedangkan Lembaga Amil Zakat merupakan lembaga yang dibentuk oleh organisasi kemasyarakatan yang bertugas untuk mengumpulkan, mendistribusikan dan mendayagunakan zakat (Rosyidah \& Manzilati, 2012).

Muzakki yang percaya pada lembaga amil zakat, mereka akan terus membayarkan zakatnya kepada lembaga amil zakat tersebut (Nasim \& Romdhon, 2014). Salah satu lembaga amil zakat (LAZ) di Indonesia yang berperan dalam pengelolaan dana zakat secara professional adalah lembaga amil zakat Dompet Amanah Umat. Penelitian yang dilakukan Septiarini (2011), menunjukkan bahwa transparansi laporan keuangan dapat dianalogikan sebagai suatu sifat dan sikap organisasi pengelola zakat yaitu tabligh, sedangkan akuntabilitas laporan keuangan dapat dianalogikan sebagai suatu sifat dan sikap organisasi pengelola zakat yaitu amanah.

Dalam Q.S. An Nisa' ayat 58 Allah SWT berfirman:

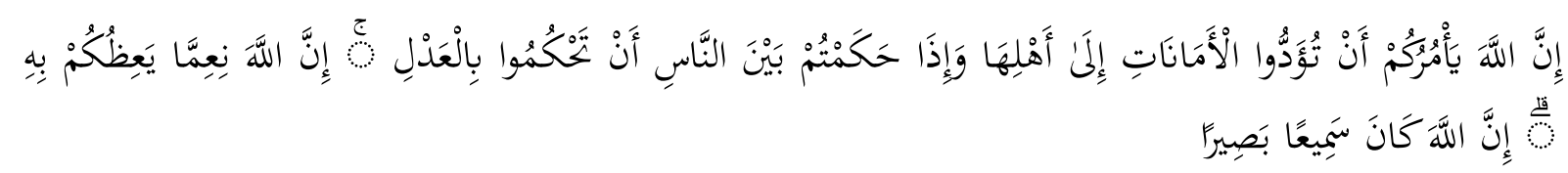

Ayat di atas memiliki pesan bahwa suatu lembaga pengelola zakat harus memegang aturan Allah, selalu meyampaikan segala sesuatu secara benar dan transparan, menjunjung tinggi kejujuran, melakukan pekerjaan dengan penuh dedikasi dan loyalitas yang tinggi. 
Selain itu, lembaga pengelola zakat harus dapat dipercaya dalam melakukan pengumpulan, penyimpanan dan pendistribusian dana ZIS kepada mereka yang berhak. Jika tidak melakukan prinsip-prinsip di atas maka bisa dipastikan lembaga tersebut tidak akan maju dan berkembang dan bahkan musnah ditelan masa sebagaimana sabda Rasulullah SAW yang berbunyi:

$$
\text { قال \}إذا ضيّعت الأمانة فانتظر السّاعة \{قيل: كيف إضاعتها؟ قال: \} إذا وسد الأمر إلى غير أهله }
$$

"Jika amanat telah hilang, tunggulah saat kehancuran, dikatakan, bagaimana hilangnya? Nabi berkata: jika suatu urusan diserahkan kepada yang bukan alhlinya”. (HR. Bukhari)

Nilai-nilai transparansi dan akuntabilitas yang dibangun akan merujuk pada good corporate governance karena berkaitan dengan pengelolaan yang baik pada sebuah lembaga (Pratiwi \& Ridlwan, 2019). Dikarenakan ruang lingkup penelitian ini adalah lembaga pengelola zakat, maka penelitian ini lebih menekankan pada penerapan Islamic Good Corporate Governance. Studi yang dilakukan oleh Abu-Tapanjeh (2009), mengemukakan prinsip-prinsip corporate governance dalam perspektif Islam diwujudkan melalui kerangka Syariah dalam pelaksanaan bisnis, keadilan, dan kesetaraan demi kemaslahatan serta berorientasi pada Allah SWT sebagai pemilik dan otoritas tunggal di dunia. Dengan demikian, Islamic corporate governance menekankan bahwa semua kegiatan bisnis harus mengacu pada Syariah Islam (Nugroho, 2015).

Penelitian ini dilakukan di lembaga amil zakat dompet amanah umat kabupaten Sidoarjo yang telah menerapkan transparansi dan akuntabilitas pengelolaan zakat. Selain itu, lembaga amil zakat dompet amanah umat kabupaten Sidoarjo sudah menerapkan prinsip Islamic good corporate governance diantaranya adalah larangan riba, maysir dan gharar, melaksanakan perilaku hidup yang beretika dengan menjunjung tinggi kesopanan, keadilan, giat mencari ilmu pengetahuan, rajin, kompeten dibidangnya, menjunjung tinggi kepentingan stakeholders, persaingan yang sehat, keterbukaan, kerahasiaan, harga dan upah yang adil (Alam Choudhury \& Nurul Alam, 2013).

Kebaruan penelitian ini adalah menggunakan pendekatan Islamic good corporate governance sebagai determinan tingkat kepercayaan muzakki. Dengan demikian, penelitian ini bertujuan untuk menguji tingkat akuntabilitas, transparansi, dan islamic good corporate governance terhadap tingkat kepercayaan muzakki di lembaga amil zakat dompet amanah umat Sidoarjo. Penelitian ini penting dilakukan karena memberikan kontribusi bagi lembaga amil zakat dompet amanah umat kabupaten Sidoarjo dalam mengembangkan dan memperluas penjaringan muzakki potensial di kabupaten Sidoarjo dan sekitarnya. Selain itu, penelitian ini dapat membuka mindset bagi calon muzakki yang akan mendistribusikan kelebihan dana mereka di lembaga yang terpercaya, professional, dan amanah.

\section{Kajian Pustaka}

Kepercayaan didefinisikan oleh Mayer, dkk (1995) sebagai kesediaan satu pihak untuk mempercayai pihak lain yang didasarkan pada harapan bahwa pihak lain tersebut akan melakukan tindakan tertentu yang penting bagi pihak yang mempercayainya. Selain itu, Mayer, dkk (1995) mengembangkan model dimensi dari kepercayaan diantaranya yakni ability, benevolence, dan integrity. Lebih jauh lagi Cazier (2007) memberikan pemahaman tentang terbentuknya kepercayaan, yaitu kepercayaan berdasarkan proses, kepercayaan berdasarkan institusi, dan kepercayaan berdasarkan karakteristik. Kepercayaan berdasarkan proses mengacu pada proses pertukaran sosial, pengalaman diantara organisasi dengan konsumen, ataupun sekedar mendengar cerita dari teman. Selanjutnya kepercayaan 
berdasarkan institusi mengacu pada penggunaan orang ketiga, seperti agen ataupun bank. Sedangkan kepercayaan berdasarkan karakteristik mengacu pada kongruensi nilai, latar belakang, etnis, dan pengalaman yang dibagikan antara penjual dan pembeli.

Tingkat kepercayaan dapat diukur dengan menggunakan empat elemen diantaranya exhibiting trust, achieving results, acting with integrity, dan demonstrating concern (Lendra \& Andi, 2006). Pengukuran tingkat exhibiting trust untuk mengetahui tingkat kepercayaan yang sekarang sudah ada pada suatu organisasi. Sedangkan achieving results merupakan kemampuan untuk mempertahankan hasil sesuai dengan komitmen yang telah dijanjikan. Sementara acting with integrity prinsip yang diperlukan untuk memenangkan atau meraih kepercayaan orang lain. Dan demonstrating concern merupakan bentuk perhatian dan kepedulian seseorang terhadap orang lain.

Transparansi memiliki makna yang sama dengan tabligh, dimana di dalam Q.S. AlMaidah Ayat 67 yang berbunyi:

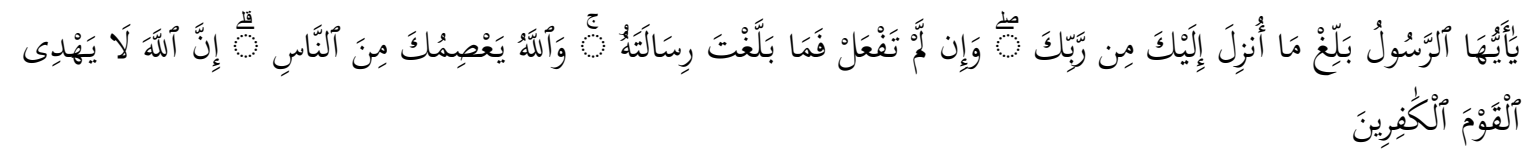

"Hai Rasul, sampaikanlah apa yang diturunkan kepadamu dari Tuhanmu. Dan jika tidak kamu kerjakan (apa yang diperintahkan itu, berarti) kamu tidak menyampaikan amanat-Nya. Allah memelihara kamu dari (gangguan) manusia. Sesungguhnya Allah tidak memberi petunjuk kepada orang-orang yang kafir." Ayat tersebut menjelaskan bahwa transparansi merupakan salah satu aspek dalam sistem tata kelola lembaga zakat yang baik. Transparansi menuntut adanya pertanggungjawaban terbuka, aksesabilitas terhadap laporan keuangan dengan mudah serta adanya publikasi laporan keuangan, hak untuk tahu hasil audit dan ketersediaan informasi kinerja lembaga (Istiqomah \& Asrori, 2019).

Prinsip transparansi menurut Rahmanurrasjid (2008) dapat diukur melalui sejumlah indikator diantaranya mekanisme yang menjamin sistem keterbukaan dan standarisasi dari semua proses-proses pelayanan publik; mekanisme yang memfasilitasi pertanyaanpertanyaan publik tentang berbagai kebijakan dan pelayanan publik, maupun proses-proses di dalam sektor publik; dan mekanisme yang memfasilitasi prlaporan maupun penyebaran informasi maupun penyimpangan tindakan aparat publik di dalam kegiatan melayani.

Akuntabilitas merupakan unsur yang penting sebagai salah satu asas pengelolaan zakat, akuntabilitas memiliki makna yang sama dengan amanah. Dalam Q.S. An-Nisa ayat 58 yang berbunyi:

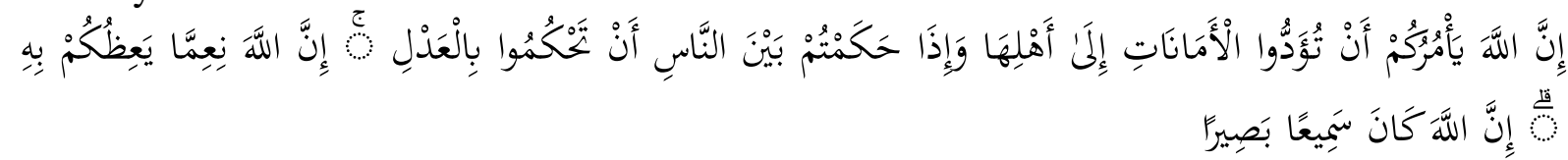

"Sesungguhnya Allah menyuruh kamu menyampaikan amanat kepada yang berhak menerimanya, dan (menyuruh kamu) apabila menetapkan hukum di antara manusia supaya kamu menetapkan dengan adil. Sesungguhnya Allah memberi pengajaran yang sebaikbaiknya kepadamu. Sesungguhnya Allah adalah Maha Mendengar lagi Maha Melihat”. Ayat tersebut menjelaskan kedudukan amanah di muka bumi oleh Allah SWT. Selain itu, akuntabilitas menurut penelitian Raeni (2014) memberikan pertanggungjawaban atas program yang dilaksanakan dalam sektor publik termasuk lembaga pengelola zamat kepada stakeholders sehingga dapat digunakan sebagai bahan pengambilan keputusan.

Terdapat beberapa karakteristik pokok sistem akuntabilitas berdasarkan perspektif sistem akuntabilitas (Sadjiarto, 2000), diantaranya berfokus pada hasil (outcomes); menggunakan beberapa indikator yang telah dipilih untuk mengukur kinerja; menghasilkan 
informasi yang berguna bagi pengambil keputusan atas suatu program atau kebijakan; menghasilkan data secara konsisten dari waktu ke waktu; dan melaporkan hasil (outcomes) dan mempublikasikannya secara teratur.

Istilah Islamic good corporate governance secara secara tersurat tidak termaktub dalam al-Qur'an, namun secara tersirat Allah SWT telah menjelaskan di dalam surat alBaqarah ayat 282 yang berbunyi:

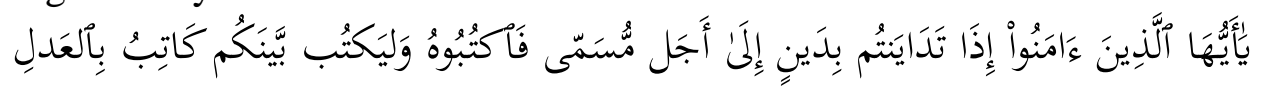

"Hai orang-orang yang beriman, apabila kamu bermu'amalah tidak secara tunai untuk waktu yang ditentukan, hendaklah kamu menuliskannya. Dan hendaklah seorang penulis di antara kaтu menuliskannya dengan benar." Ayat tersebut menjelaskan berapa pentingnya menjaga catatan secara tepat dan akurat sehingga tidak ada pihak yang dirugikan dan diperlakukan tidak adil.

Corporate governance merupakan seperangkat peraturan yang mengatur hubungan antara pemegang saham, pengurus (pengelola) perusahaan, pihak kreditur, pemerintah, karyawan, serta para pemegang kepentingan internal dan eksternal lainnya yang berkaitan dengan hak-hak dan kewajiban mereka atau dengan kata lain suatu sistem yang mengendalikan perusahaan dengan tujuan untuk menciptakan nilai tambah bagi semua pihak yang berkepentingan stakeholders (Effendi, 2009). Sedangkan good corporate governance adalah proses pengelolaan perusahaan secara konseptual menyangkut diaplikasikannya prinsip-prinsip fairness, transparency, accountability, independency dan responsibility, terutama ditujukan kepada perusahaan publik, Badan Usaha Milik Negara (BUMN), perusahaan-perusahaan yang menggunakan dana publik dan ikut dalam pengelolaan dana publik (Sutojo \& Aldridge, 2005). Dalam konteks lembaga pengelola zakat, penerapan good corporate governance dapat dilakukan dengan mengadopsi Islamic good corporate governance (IGCG) yang dapat diukur dengan prinsip keseimbangan dan keadilan, tauhid, taqwa dan ridho, dan kemaslahatan (Pratiwi \& Ridlwan, 2019).

Motivasi seseorang membayar zakat adalah sebagai bentuk syukur atas harta dan kenikmatan yang telah diberikan kepada Allah SWT. Pentingnya transparansi dalam menyelenggarakan dana zakat sangat mempengaruhi tingkat kepercayaan muzakki terhadap lemabaga zakat. Penelitian yang dilakukan oleh Nasim \& Romdhon (2014) menunjukkan bahwa transparansi laporan keuangan berpengaruh signifikan terhadap tingkat kepercayaan muzakki. Senada dengan penelitian Nasim \& Romdhon, terdapat beberapa penelitian yang menunjukkan hubungan yang signifikan antara transparansi dan tingkat kepercayaan muzakki (Istiqomah \& Asrori, 2019; Rahayu, Widodo, \& Binawati, 2019). Berdasarkan uraian diatas, maka hipotesis penelitian ini yaitu:

\section{$H_{1}$ : Semakin tinggi tingkat transparansi lembaga pengelola zakat, maka semakin tinggi tingkat kepercayaan muzakki.}

Akuntabilitas harus diutamakan karena memiliki dampak kepada minat muzakki dalam membayarkan zakatnya. Pengaruh antara akuntabilitas lembaga pengelola zakat dengan tingkat kepercayaan muzakki dilihat dari konsistensi muzakki dalam membayar zakat kepada mustahiq secara terus menerus. Penelitian yang dilakukan oleh Hasrina, dkk (2018) menunjukkan bahwa akuntabilitas memiliki pengaruh yang signifikan terhadap tingkat kepercayaan muzakki. Senada dengan penelitian Hasrina, dkk., terdapat beberapa penelitian yang menunjukkan hubungan signifikan antara akuntabilitas terhadap tingkat kepercayaan muzakki (Nasim \& Romdhon, 2014; Septiarini, 2011). Berdasarkan uraian diatas, maka hipotesis penelitian ini yaitu: 


\section{$\mathrm{H}_{2}$ : Semakin tinggi tingkat akuntabilitas lembaga pengelola zakat, maka semakin tinggi tingkat kepercayaan muzakki.}

Lembaga keuangan syariah harus mengacu pada prinsip-prinsip Islamic corporate governance. Entitas syariah tentunya memiliki perspektif tersendiri terhadap corporate governance yang merupakan cerminan perspektif Islam. Good corporate governance dalam perspektif islam menekankan peletakan ideologi tauhid dalam perspektif syariah. Dalam pandangan islam, good corporate governance harus mengintegrasikan aspek peraturan yang didasarkan pada syariah dan ajaran moral Islam sebagai intinya (Rahman, 1998). Penelitian yang dilakukan oleh Nugroho (2015) menunjukkan bahwa Baitul Maal Wat Tamwil harus mereformasikan dengan mengimplementasikan Islamic corporate governance yang merupakan prinsip tata kelola perusahaan berlandaskan prinsip syariah Islam, dimana tujuannya yaitu untuk mempertahankan siatuasi persaingan yang sehat.

Dalam konteks tata kelola lemabaga yang baik, penelitian yang dilakukan oleh Kuncaraningsih \& Ridla (2015) menunjukkan bahwa good corporate governance berpengaruh secara positif dan signifikan terhadap kepuasan muzakki di BAZNAS Kabupaten Sleman. Hasil yang serupa juga ditunjukkan oleh penelitian yang dilakukan oleh Pratiwi \& Ridlwan (2019), dimana secara parsial religiusitas Islami, Islamic good corporate governance dan motivasi islam berpengaruh secara signifikan terhadap kepercayaan muzakki pada amil zakat di Surabaya. Berdasarkan uraian diatas, maka hipotesis penelitian ini yaitu:

\section{$H_{3}$ : Islamic good corporate governance berpengaruh secara signifikan terhadap tingkat kepercayaan muzakki.}

\section{Metode Penelitian}

Jenis penelitian yang digunakan adalah penelitian kuantitatif dengan instrument penelitian yang digunakan adalah kuesioner online yang disebarkan kepada seluruh muzakki tetap lembaga amil zakat dompet amanah umat kabupaten Sidoarjo. Penelitian ini bertujuan untuk mengetahui pengaruh transparansi, akuntabilitas dan Islamic good corporate governance terhadap tingkat kepercayaan muzakki di lembaga amil zakat dompet amanah umat Sidoarjo.

Populasi dalam penelitian ini yaitu seluruh muzakki tetap maupun yang pernah melakukan pembayaran zakat infaq, dan shodaqoh di lembaga amil zakat dompet amanah umat kabupaten Sidoarjo. Teknik pengambilan sampel adalah nonprobability sampling dengan pendekatan accidental sampling. Dimana pengambilan sampel yang secara kebetulan, sehingga siapa saja muzakki yang ditemui dan sesuai untuk digunakan sebagai sumber data. Selain itu, perhitungan accidental sampling menggunakan rumus Lemeshow yang berkaitan dengan banyaknya populasi yang tidak diketahui (Sugiyono, 2008).

Teknik analisis data menggunakan regresi linear berganda dengan software SPSS 24. Teknik analisis data yang dilakukan meliputi uji kualitas data yang meliputi uji validitas menggunakan product moment pearson dengan titik kritis $>0,30$ dan uji reliabilitas menggunakan cronbach alpha dengan titik kritis $>0,60$. Selain uji kualitas data, analisis selanjutnya menggunakan uji asumsi klasik yang terdiri atas uji normalitas data, multikolinearitas, autokorelasi dan heteroskedastisitas (Supranto, 2016).

Pengujian hipotesis dilakukan dengan menggunakan perbandingan nilai $t$-hitung dan $t$ tabel serta nilai signifikan probabilitas dengan tingkat kesalahan 5\%. Selain itu, pengujian 
hipotesis juga menggunakan tingkat koefisien determinasi $\left(R^{2}\right)$ untuk mengetahui besaran pengaruh variabel independen terhadap variabel dependen (Junjunan, 2018; Sugiyono, 2013).

Adapun persamaan regresi linear berganda penelitian ini adalah sebagai berikut:

Dimana

$$
\mathrm{Y}=\alpha+\beta_{1} \cdot \mathrm{X}_{1}+\beta_{2} \cdot \mathrm{X}_{2}+\beta_{3} \cdot \mathrm{X}_{3}+e
$$

Y : Kepercayaan muzakki

$\alpha \quad$ : Nilai konstanta

$\beta_{1} \quad$ : Koefisien variabel Tranparansi

$\beta_{2} \quad$ : Koefisien variabel Akuntabilitas

$\beta_{3} \quad$ : Koefisien variabel Islamic good corporate governance (IGCG)

$\mathrm{X}_{1} \quad$ : Transparansi

$\mathrm{X}_{2} \quad$ : Akuntabilitas

$\mathrm{X}_{3}$ : Islamic good corporate governance (IGCG)

e : Nilai error

\section{Hasil dan Pembahasan}

Responden dalam penelitian yaitu muzakki lembaga amil zakat dompet amanah umat kabupaten Sidoarjo. Profil responden meliputi usia, status pernikahan dan lama waktu menjadi muzakki di lembaga amil zakat dompet amanah umat.

\section{Tabel 1}

Usia Responden

\begin{tabular}{|c|l|r|r|r|r|}
\hline \multicolumn{2}{|c|}{} & Frequency & Percent & $\begin{array}{c}\text { Valid } \\
\text { Percent }\end{array}$ & $\begin{array}{c}\text { Cumulative } \\
\text { Percent }\end{array}$ \\
\hline \multirow{3}{*}{ Valid } & $17-25$ Tahun & 18 & 42.9 & 42.9 & 42.9 \\
\cline { 2 - 6 } & $26-35$ Tahun & 15 & 35.7 & 35.7 & 78.6 \\
\cline { 2 - 6 } & $>35$ Tahun & 9 & 21.4 & 21.4 & 100.0 \\
\cline { 2 - 6 } & Total & 42 & 100.0 & 100.0 & \\
\hline
\end{tabular}

Berdasarkan tabel 1 diatas dapat diketahui bahwa usia muzakki terbanyak yang menjadi responden penelitian berkisar antara 17 hingga 25 tahun sebesar 42,9\% atau sebanyak 18 orang, dan yang paling sedikit berusia diatas 35 tahun. Kemudian responden dengan lama waktu menjadi muzakki dari 1 hingga 5 tahun merupakan responden terbanyak dalam penelitian sebesar $85,7 \%$ atau sebanyak 36 orang, dan sisanya adalah responden dengan lama waktu menjadi muzakki berkisar antara 6 hingga 10 tahun sebanyak 6 orang. 
Tabel 2

Lama menjadi Muzakki

\begin{tabular}{|c|l|r|r|r|r|}
\hline \multicolumn{2}{|c|}{} & Frequency & Percent & $\begin{array}{c}\text { Valid } \\
\text { Percent }\end{array}$ & $\begin{array}{c}\text { Cumulative } \\
\text { Percent }\end{array}$ \\
\hline \multirow{2}{*}{ Valid } & $1-5$ Tahun & 36 & 85.7 & 85.7 & 85.7 \\
\cline { 2 - 6 } & $6-10$ Tahun & 6 & 14.3 & 14.3 & 100.0 \\
\cline { 2 - 6 } & Total & 42 & 100.0 & 100.0 & \\
\hline
\end{tabular}

Uji kualitas data dalam penelitian ini menggunakan uji validitas dan reliabilitas guna melihat keyakinan dan kehandalan instrumen data yang digunakan di dalam penelitian. Hasil uji kualitas data menunjukkan bahwa seluruh indikator dari variabel penelitian valid dan reliabel sehingga layak untuk dilakukan pengujian asumsi klasik. Sementara uji asumsi klasik dalam penelitian ini menggunakan uji normalitas, uji multikolinearitas, dan uji heteroskedastisitas.

Tabel 3

One-Sample Kolmogorov-Smirnov Test

\begin{tabular}{|c|c|c|}
\hline & & $\begin{array}{l}\text { Unstandardized } \\
\text { Residual }\end{array}$ \\
\hline \multicolumn{2}{|l|}{$\mathrm{N}$} & 42 \\
\hline \multirow[t]{2}{*}{ Normal Parameters ${ }^{\mathrm{a}, \mathrm{b}}$} & Mean & .0000000 \\
\hline & $\begin{array}{l}\text { Std. } \\
\text { Deviation }\end{array}$ & 1.98921737 \\
\hline \multirow{3}{*}{$\begin{array}{l}\text { Most Extreme } \\
\text { Differences }\end{array}$} & Absolute & .088 \\
\hline & Positive & .088 \\
\hline & Negative & -.080 \\
\hline \multicolumn{2}{|l|}{ Test Statistic } & .088 \\
\hline \multicolumn{2}{|l|}{ Asymp. Sig. (2-tailed) } & $.200^{\mathrm{c}, \mathrm{d}}$ \\
\hline \multicolumn{3}{|c|}{$\begin{array}{l}\text { a. Test distribution is Normal. } \\
\text { b. Calculated from data. } \\
\text { c. Lilliefors Significance Correction. } \\
\text { d. This is a lower bound of the true sign }\end{array}$} \\
\hline
\end{tabular}

Berdasarkan tabel 3 menunjukkan nilai signifikansi kolmogorov-smirnov lebih tinggi daripada 0,05 . Hal ini membuktikan residual data penelitian terdistribusi dengan normal. Kemudian berdasarkan tabel 4 menunjukkan nilai tolerance masing-masing variabel mendekati nilai 1 dan nilai VIF masing-masing variabel lebih kecil dari nilai 10 , sehingga variabel data penelitian dapat dikatakan lolos dari problem multikolinearitas. 
Tabel 4

Coefficients $^{\mathrm{a}}$

\begin{tabular}{|c|c|c|c|c|c|c|c|c|}
\hline & \multirow{2}{*}{ Model } & \multicolumn{2}{|c|}{$\begin{array}{l}\text { Unstandardized } \\
\text { Coefficients }\end{array}$} & \multirow{2}{*}{$\begin{array}{c}\text { Standardized } \\
\text { Coefficients }\end{array}$} & \multirow{2}{*}{$\mathrm{T}$} & \multirow{2}{*}{ Sig. } & \multicolumn{2}{|c|}{$\begin{array}{l}\text { Collinearity } \\
\text { Statistics }\end{array}$} \\
\hline & & B & $\begin{array}{l}\text { Std. } \\
\text { Error }\end{array}$ & & & & Tolerance & VIF \\
\hline \multirow[t]{4}{*}{1} & (Constant) & 10.480 & 4.545 & & 2.306 & .027 & & \\
\hline & Transparansi & .675 & .180 & .446 & 3.744 & .001 & .843 & 1.186 \\
\hline & Akuntabilitas & .080 & .210 & .056 & .380 & .706 & .557 & 1.796 \\
\hline & IGCG & .626 & .215 & .417 & 2.910 & .006 & .582 & 1.718 \\
\hline
\end{tabular}

a. Dependent Variable: Kepercayaan Muzakki

Gambar hasil uji heteroskedastisitas membentuk gambar titik-titik dengan pola yang tidak jelas, selain itu titik-titik menyebar diatas dan dibawah angka 0 pada sumbu dependen, sehingga disimpulkan bahwa tidak terjadi masalah heteroskedastisitas pada model regresi kepercayaan muzakki. Setelah lolos dari seluruh asumsi maka analisis dapat dilanjutkan dengan melakukan uji hipotesis menggunakan nilai signifikansi dan uji $\mathrm{T}$.

\section{Pengaruh transparansi lembaga pengelola zakat terhadap tingkat kepercayaan muzakki}

Berdasarkan tabel 4 menunjukkan bahwa transparansi berpengaruh positif terhadap tingkat kepercayaan muzakki. Hasil ini dapat diketahui dari nilai probabilitas yang kurang dari $0,05(0,027<0,05)$ dan nilai t-hitung yang lebih besar daripada nilai t-tabel $(2,306>$ 2,024), sehingga hasil tersebut mendukung hipotesis pertama penelitian dimana semakin tinggi tingkat transparansi lembaga pengelola zakat, maka semakin tinggi tingkat kepercayaan muzakki. Hasil penelitian ini mendukung kajian yang dilakukan tentang transparansi lembaga pengelola zakat yang baik dengan tingkat kepercayaan muzakki yang memberikan dananya untuk zakat, infaq dan shodaqoh di jalan Allah (Istiqomah \& Asrori, 2019; Nasim \& Romdhon, 2014; Rahayu et al., 2019). Hasil penelitian ini didukung karena laporan keuangan lembaga amil zakat dompet amanah umat diterbitkan secara periodik. Disamping itu, lembaga dengan segala kerja kerasnya memaparkan segala aktivitas pengelolaan zakat kepada muzakki, mengungkapkan kondisi keuangan dan mempublikasikan laporan keuangan secara menyeluruh kepada pihak yang berkepentingan.

\section{Pengaruh Islamic good corporate governance terhadap tingkat kepercayaan muzakki}

Hasil selanjutnya menunjukkan bahwa Islamic good corporate governance (IGCG) berpengaruh positif terhadap kepercayaan muzakki. Argumen tersebut dapat diketahui dari nilai probabilitas di tabel 4 yang kurang dari $0,05(0,006<0,05)$ dan nilai t-hitung yang lebih besar daripada nilai t-tabel $(2,910>2,024)$, sehingga hasil tersebut mendukung hipotesis ketiga penelitian dimana penerapan Islamic good corporate governance lembaga pengelola zakat berpengaruh secara signifikan terhadap tingkat kepercayaan muzakki. Hasil penelitian ini mendukung studi yang dilakukan oleh Kuncaraningsih \& Ridla (2015) dan Pratiwi \& Ridlwan (2019). Selain itu, hasil penelitian ini mengindikasikan bahwa lembaga penglola zakat dalam hal ini lembaga amil zakat dompet amanah umat secara tata kelola organisasi berbasis Islam sudah diterapkan dengan sangat baik, dengan demikian kepercayaan muzakki meningkat seiring dengan adanya pengelolaan zakat yang baik. Tidak hanya itu, lembaga amil zakat dompet amanah umat dalam mengelola zakat sangat mengedepankan keyakinan 
yang teguh kepada Allah swt, bekerja dengan penuh taqwa dan ridho Allah swt, serta dalam pendistribusian zakat kepada para mustahiq dilakukan dengan sangat adil dan merata.

Tabel 5

Model Summary ${ }^{b}$

\begin{tabular}{|l|r|r|r|r|}
\hline Model & R & R Square & $\begin{array}{c}\text { Adjusted R } \\
\text { Square }\end{array}$ & $\begin{array}{c}\text { Std. Error of } \\
\text { the Estimate }\end{array}$ \\
\hline 1 & $.739^{\mathrm{a}}$ & .546 & .510 & 2.06625 \\
\hline
\end{tabular}

a. Predictors: (Constant), IGCG, Transparansi, Akuntabilitas

b. Dependent Variable: Kepercayaan Muzakki

\section{Pengaruh akuntabilitas lembaga pengelola zakat terhadap tingkat kepercayaan muzakki}

Hasil yang berbeda ditunjukkan oleh variabel akuntabilitas. Akuntabilitas dalam penelitian ini tidak mampu mempengaruhi tingkat kepercayaan muzakki secara signifikan. Argumen tersebut dapat diketahui dari tabel 4 yang menunjukkan bahwa nilai probabilitas lebih besar dari $0,05(0,706>0,05)$ dan nilai t-hitung yang lebih kecil daripada nilai t-tabel $(0,380<2,024)$, sehingga hasil tersebut tidak mendukung hipotesis kedua penelitian. Hasil penelitian ini disebabkan karena lembaga amil zakat dompet amanah umat tidak sepenuhnya mengungkapkan segala informasi terkait aktivitas dan kinerja finansial kepada pengguna laporan. Selain itu, beberapa program lembaga amil zakat dompet amanah umat belum sepenuhnya mampu meningkatkan kesejahteraan mustahik.

Meskipun akuntabilitas menjadi variabel yang tidak dapat menentukan tingkat kepercayaan muzakki, namun besar pengaruh variabel transparansi, akuntabilitas, dan Islamic good corporate governance secara bersama-sama terhadap tingkat kepercayaan muzakki yang ditunjukkan oleh besarnya $R$-square sebesar $54,6 \%$ dan sisanya sebesar $45,4 \%$ dipengaruhi oleh variabel lain yang berada diluar model yang ditunjukkan oleh tabel 5 .

\section{Kesimpulan}

Berdasarkan hasil penelitian dapat disimpulkan bahwa transparansi pada lembaga amil zakat memiliki pengaruh yang positif terhadap tingkat kepercayaan muzakki. Semakin transparan lembaga amil zakat dompet amanah umat dalam mengelola keuangan dan zakat, maka muzakki semakin yakin untuk memberikan dananya yang kemudian disalurkan kepada mustahiq. Selain itu, hasil penelitian juga menemukan bahwa Islamic good corporate governance yang diterapkan oleh lembaga amil zakat dompet amanah umat memiliki pengaruh yang positif signifikan terhadap tingkat kepercayaan muzakki. Namun, secara akuntabilitas lembaga amil zakat dompet amanah umat tidak mampu mempengaruhi tingkat kepercayaan masyarakat. Hal ini disebabkan karena lembaga tidak mampu mengungkapkan segala informasi yang berkaitan dengan aktivitas dan kinerja finansial kepada pengguna laporan.

Penelitian ini hanya dilakukan pada lembaga amil zakat dompet amanah umat yang berada di kabupaten sidoarjo. Selain itu, penelitian ini belum menggunakan variabel tata kelola organisasi secara utuh seperti independensi, responsibility, dan fairness dikarenakan obyek penelitian di lembaga amil zakat dompet amanah umat tergolong masih baru. Dengan demikian, penelitian selanjutnya dapat memperluas sampel dan menambahkan beberapa variabel tata kelola organisasi yang baik. 


\section{Daftar Pustaka}

Abu-Tapanjeh, A. M. (2009). Corporate governance from the Islamic perspective: A comparative analysis with OECD principles. Critical Perspectives on Accounting. https://doi.org/10.1016/j.cpa.2007.12.004

Alam Choudhury, M., \& Nurul Alam, M. (2013). Corporate governance in Islamic perspective. International Journal of Islamic and Middle Eastern Finance and Management, 6(3), 180-199. https://doi.org/10.1108/IMEFM-10-2012-0101

Atabik, A. (2015). Peranan zakat dalam pengentasan kemiskinan. ZISWAF: Jurnal Zakat Dan Wakaf, 2(2), 339-361.

Cazier, J. A. (2007). A framework and model for understanding the creation and sources of trust. Journal of International Technology and Information Management, 16(2), 44-56.

Effendi, M. A. (2009). The power of good corporate governance: teori dan implementasi. Jakarta: Salemba Empat.

Ghofur, A. (2010). Implementasi Undang-Undang Nomor 38 Tahun 1999 Tentang Pengelolaan Zakat Di Lembaga Kemanusiaan Indonesia Dana. Universitas Sebelas Maret Surakarta.

Hasrina, C. D., Yusri, \& Agusti, D. R. (2018). Pengaruh Akuntabilitas dan Transparansi Lembaga Zakat Terhadap Tingkat Kepercayaan Muzakki Dalam Membayar Zakat Di Baitul Mal Kota Banda Aceh. Humaniora, 2(1), 1-9.

Istiqomah, D., \& Asrori. (2019). Pengaruh literasi terhadap kepercayaan muzaki pada lembaga pengelola zakat dengan akuntabilitas dan transparansi sebagai variabel intervening. Economic Education Analysis Journal, 8(1), 95-109.

Junjunan, M. I. (2018). Pengaruh partisipasi anggaran terhadap sikap kreatif yang dimediasi oleh psychological capital di sekolah Muhammadiyah Jawa Timur. Universitas Airlangga Surabaya.

Kuncaraningsih, H. S., \& Ridla, M. R. (2015). Good Corporate Governance Dalam Meningkatkan Kepuasan Muzzaki di Badan Amil Zakat Nasional. Jurnal MD Membangun Profesionalisme Keilmuan, 97-115.

Lendra, \& Andi. (2006). Tingkat Kepercayaan Dalam Hubungan Kemitraan. Civil Engineering Dimension, 8(2), 55-62.

Mayer, R. C., Davis, J. H., \& Schoorman, F. D. (1995). An Integrative Model of Organizational Trust. Academy of Management Review, 20(3), 709-734. Retrieved from http://www.ncbi.nlm.nih.gov/pubmed/7465305

Nasim, A., \& Romdhon, M. R. S. (2014). Pengaruh Transparansi Laporan Keuangan, Pengelolaan Zakat, dan Sikap Pengelola terhadap Tingkat Kepercayaan Muzakki. Jurnal Riset Akuntansi Dan Keuangan. https://doi.org/10.17509/jrak.v2i3.6603

Nugroho, M. A. S. (2015). Urgensi Penerapan Islamic Corporate Governance di Baitul Maal Wat Tamwil (BMT). Jurnal Kajian Bisnis, 23(1), 64-70.

Pratiwi, D. W., \& Ridlwan, A. A. (2019). Pengaruh Religiusitas, IGCG, dan Motivasi terhadap Kepercayaan Muzaki pada Amil Zakat Surabaya. Jurnal Ekonomi Islam, 2(3), $72-81$.

Purbasari, I. (2015). Pengelolaan Zakat oleh Badan dan Lembaga Amil Zakat di Surabaya dan Gresik. Mimbar Hukum, 27(1), 68-81.

Raeni, R. (2014). Pengaruh prinsip keadilan, efisiensi, transparansi, dan akuntabilitas pengelolaan keuangan terhadap produktivitas SMK. Economic Education Analysis Journal, 3(1).

Rahayu, S. B., Widodo, S., \& Binawati, E. (2019). Pengaruh akuntabilitas dan transparansi lembaga zakat terhadap tingkat kepercayaan muzakki. Journal of Business and 
Information Systems, 1(2), 103-114. https://doi.org/10.36067/jbis.v1i2.26

Rahman, A. R. A. (1998). Issues in Corporate Accountability and Govenance: An Islamic Perspective. The American Journal of Islamic Social Sciences.

Rahmanurrasjid, A. (2008). Akuntabilitas dan Transparansi dalam Pertanggungjawaban Pemerintah Daerah untuk Mewujudkan Pemerintahan yang Baik di Daerah. Universitas Diponegoro Semarang.

Rosyidah, T. A., \& Manzilati, A. (2012). Implementasi Undang-Undang Nomor 23 Tahun 2011 Terhadap Legalitas Pengelolaan Zakat Oleh Lembaga Amil Zakat (Studi Pada Beberapa LAZ Di Kota Malang). Jurnal Ilmiah Mahasiswa FEB, 1(1), 32.

Rozalinda. (2016). Teori dan Aplikasinya pada Aktivitas Ekonomi. Jakarta.

Sadjiarto, A. (2000). Akuntabilitas Dan Pengukuran Kinerja Pemerintahan. Jurnal Akuntansi Dan Keuangan, 2(2), 138-150. https://doi.org/10.9744/jak.2.2.pp.138-150

Septiarini, D. F. (2011). Pengaruh Transparansi Dan Akuntabilitas Terhadap Pengumpulan Dana Zakat, Infaq Dan Shodaqoh Pada Laz Di Surabaya. AKRUAL: Jurnal Akuntansi, 2(2), 172. https://doi.org/10.26740/jaj.v2n2.p172-199

Sugiyono. (2008). Metode Penelitian Bisnis: Pendekatan Kuantitatif, Kualitatif, dan R\&D. Bandung: Penerbit Alfabeta.

Sugiyono, P. D. (2013). Metode Penelitian Kuantitatif, Kualitatif, dan R\&D. Jakarta: CV Alfabeta.

Supranto, J. (2016). Statistik Teori dan Aplikasi. Jakarta: Penerbit Erlangga.

Sutojo, S., \& Aldridge, E. J. (2005). Good Corporate Governance Tata Kelola Perusahaan yang Sehat. Jakarta: PT Danar Mulia Pustaka. 


\section{Lampiran Penelitian}

Tabel Uji Kualitas Data

\begin{tabular}{|c|c|c|c|c|c|}
\hline \multirow[t]{2}{*}{ Variabel } & \multirow[t]{2}{*}{ Indikator } & \multicolumn{2}{|c|}{ Uji Validitas } & \multicolumn{2}{|c|}{ Uji Reliabilitas } \\
\hline & & Pearson & Status $>0,30$ & Alpha & Status $>0.60$ \\
\hline \multirow[t]{5}{*}{ Transparansi } & $\mathrm{X} 11$ & 0,571 & Valid & \multirow[t]{5}{*}{0,687} & \multirow[t]{5}{*}{ Reliabel } \\
\hline & $\mathrm{X} 12$ & 0,629 & Valid & & \\
\hline & $\mathrm{X} 13$ & 0,675 & Valid & & \\
\hline & $\mathrm{X} 14$ & 0,730 & Valid & & \\
\hline & $\mathrm{X} 15$ & 0,628 & Valid & & \\
\hline \multirow[t]{6}{*}{ Akuntabilitas } & $\mathrm{X} 21$ & 0,504 & Valid & \multirow[t]{6}{*}{0,687} & \multirow[t]{6}{*}{ Reliabel } \\
\hline & $\mathrm{X} 22$ & 0,719 & Valid & & \\
\hline & $\mathrm{X} 23$ & 0,752 & Valid & & \\
\hline & X24 & 0,615 & Valid & & \\
\hline & $\mathrm{X} 25$ & 0,484 & Valid & & \\
\hline & $\mathrm{X} 26$ & 0,661 & Valid & & \\
\hline \multirow{4}{*}{$\begin{array}{l}\text { Islamic Good } \\
\text { Corporate } \\
\text { Governance } \\
\text { (IGCG) }\end{array}$} & X31 & 0,886 & Valid & \multirow[t]{4}{*}{0,857} & \multirow[t]{4}{*}{ Reliabel } \\
\hline & X32 & 0,826 & Valid & & \\
\hline & $\mathrm{X} 33$ & 0,793 & Valid & & \\
\hline & X34 & 0,845 & Valid & & \\
\hline \multirow{9}{*}{$\begin{array}{l}\text { Kepercayaan } \\
\text { Muzakki }\end{array}$} & Y1 & 0,629 & Valid & \multirow[t]{9}{*}{0,793} & \multirow[t]{9}{*}{ Reliabel } \\
\hline & Y2 & 0,580 & Valid & & \\
\hline & Y3 & 0,603 & Valid & & \\
\hline & $\mathrm{Y} 4$ & 0,651 & Valid & & \\
\hline & Y5 & 0,705 & Valid & & \\
\hline & Y6 & 0,492 & Valid & & \\
\hline & Y7 & 0,577 & Valid & & \\
\hline & Y8 & 0,623 & Valid & & \\
\hline & Y9 & 0,662 & Valid & & \\
\hline
\end{tabular}



IGCG Terhadap Tingkat Kepercayaan Muzakki di Lembaga Amil Zakat Dompet Amanah Umat

\section{Gambar Uji Heteroskedastisitas}

\section{Scatterplot}

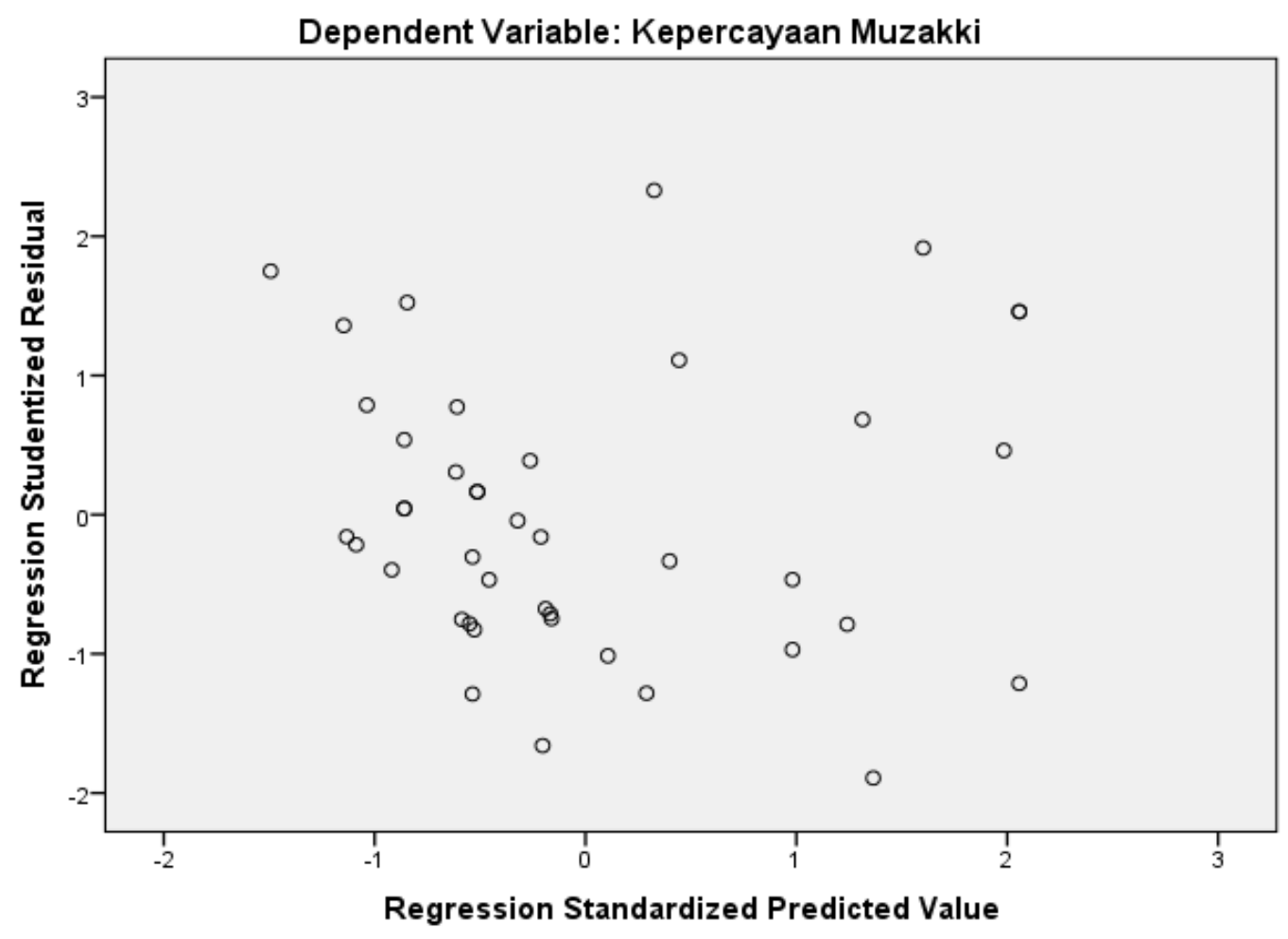

